\title{
Antibacterial Effect of Different Herbal Extracts Against Listeria monocytogenes Strains Isolated from Foods
}

\author{
Esra Şentürk $^{1, a}$, Simge Aktop ${ }^{1, b}$, Hacer Aslan Canberi ${ }^{2, c}$, Zehra Tuğçe Toprak ${ }^{1, d}$, Pınar Şanlıbaba ${ }^{1, e, *}$ \\ ${ }^{I}$ Ankara University, Engineering Faculty, Department of Food Engineering, $50^{\text {th }}$ Year Settlement, 06830 Gölbaşı/Ankara, Turkey \\ ${ }^{2}$ Ankara University, Biotechnology Institute, $60^{\text {th }}$ Year Settlement, 06110 Dışkapl/Ankara, Turkey
}

*Corresponding author

\begin{tabular}{l|l}
\hline A R T I C L E I N F O & A B S T R A C T \\
\hline Research Article & $\begin{array}{l}\text { Listeria monocytogenes is a foodborne pathogen frequently isolated from food that causes different } \\
\text { public health problems. In recent years, antibiotic resistance of pathogens has become an important } \\
\text { problem affecting human health. For this reason, it is crucial to develop an alternative to antibiotics. } \\
\text { Thus, the antibacterial effects of herbal extracts and essential oils are frequently investigated. In this } \\
\text { article, the antibacterial activity of extracts obtained from } 16 \text { different herbs using ethanol, } \\
\text { chloroform, acetone, and distilled water was evaluated against } L \text {. monocytogenes strains. The extract } \\
\text { showing the highest antibacterial effect against L. monocytogenes was St. John's Wort extracted in } \\
\text { ethanol (31.72 } \pm 0.52 \text { mm). In addition, Myrtus leaf extracted in ethanol }(27.2 \pm 0.52 \text { mm) and St. } \\
\text { John's Wort extracted in acetone (25.6 } \pm 0.52 \text { mm) showed a high antibacterial effect against } L . \\
\text { Accepted : } 01 / 07 / 2021 \\
\text { monocytogenes compared to other extracts. In the study, the solvent ethanol in which St. John's Wort } \\
\text { and Myrtus leaf were extracted showed the highest antibacterial activity. In contrast, the solvent that } \\
\text { rosemary extract showed the highest antibacterial effect was acetone. However, the most antibacterial } \\
\text { herb extracted in distilled water was peppermint (7.03 } \pm 0.52 \text { mm). The extracts of marjoram and } \\
\text { yarrow did not show any antibacterial effect in any solvent used in the study. In conclusion, more } \\
\text { studies are needed to determine the antibacterial effects of herbal extracts against pathogens in foods } \\
\text { and their use. }\end{array}$ \\
$\begin{array}{l}\text { Herbaleria monocytogenes } \\
\text { Antibacterial effect } \\
\begin{array}{l}\text { Disk diffusion method } \\
\text { Maceration }\end{array}\end{array}$
\end{tabular}

Türk Tarım - Gıda Bilim ve Teknoloji Dergisi, 9(8): 1474-1479, 2021

\section{Bitkisel Ekstraktların Gıdalardan İzole Edilen Listeria monocytogenes Suşlarına Karşı Antibakteriyel Etkisi}

M A K A L E B İ L G
Araştırma

Geliş $\quad: 10 / 03 / 2021$
Kabul $\quad: 01 / 07 / 2021$

Anahtar Kelimeler: Bitki ekstraktı

Listeria monocytogenes Antibakteriyel etki Disk difüzyon yöntemi Maserasyon

Ö Z

Listeria monocytogenes gıdalardan sıklıkla izole edilen ve çeşitli halk sağlı̆̆ sorunlarına neden olan gıda kaynaklı bir patojendir. Patojenik bakterilerin birçok antibiyotiğe karşı direnç kazanmış olması, son yıllarda insan sağlığını etkileyen önemli bir problem haline gelmiştir. Bu nedenle günümüzde antibiyotiklere alternatif yöntemler geliștirmek önemlidir. Bu amaçla, bitkilerden elde edilen ekstraktların ve esansiyel yağların antibakteriyel etkileri sıklıkla araştırılmaktadır. Bu makalede, 16 farklı bitkiden etanol, kloroform, aseton ve distile su kullanılarak elde edilen ekstraktların, L.monocytogenes suşlarına karşı antibakteriyel etkileri araştırılmıştır. Çalışma sonunda, $L$. monocytogenes'e karşı en yüksek antibakteriyel etkiyi gösteren ekstraktın, etanolde ekstrakte edilen sarı kantaron $(31,72 \pm 0,52 \mathrm{~mm})$ olduğu tespit edilmiştir. Etanolde ekstrakte edilen mersin yaprağının $(27,2 \pm 0,52 \mathrm{~mm})$ ve asetonda ekstrakte edilen sar1 kantaronun $(25,6 \pm 0,52 \mathrm{~mm})$, L. monocytogenes'e karşı antibakteriyel etki gösteren diğer ekstraktlar olduğu belirlenmiştir. Çalışmada sarı kantaron ve mersin yaprağı ekstraktlarının en fazla antibakteriyel etkiyi gösterdikleri çözücü etanol olarak bulunurken, biberiye ekstraktının en fazla antibakteriyel etkiyi gösterdiği çözücü aseton olarak bulunmuştur. Bununla birlikte, distile suda ekstrakte edilen bitkiler arasında en fazla antibakteriyel etkiyi gösteren bitkinin nane $(7,03 \pm 0,52 \mathrm{~mm})$ olduğu tespit edilmiştir. Mercanköşk ve civanperçemi ekstraktları ise çalışmada kullanılan hiçbir çözücüde antibakteriyel etki göstermemiştir. Gıdalardaki patojen bakterilere karşı bitki ekstraktlarının antibakteriyel etkilerinin ve gıdalarda kullanılabilme durumlarının belirlenmesi amacıyla daha fazla çalışmaya ihtiyaç vardır. 


\section{Introduction}

In recent years, medicinal and aromatic herbs used for their therapeutic properties since ancient times have been used as components in food, medicine, and cosmetics (Elisha et al., 2017; Mukherjee, 2019). Herbal extracts are the source of many active compounds which were important for human health. These active compounds belong to flavonoids, glycosides, phenolic compounds, alkaloids, and tannins (Rodino et al., 2015). Herbal extracts with antioxidant, anti-inflammatory, anticarcinogenic, immunomodulatory, antidiabetic, and neuroprotective effects are alternatives to synthetic drugs and supplements (Karim et al., 2018; Sogut et al., 2020). In addition, many herbs are known to have antimicrobial properties (Rodino and Butu, 2019). The changes in the structure and chemical composition of compounds found in herbs cause differences in antimicrobial effect of the herbs (Gyawali and Ibrahim, 2014). Antibacterial effects of phytochemicals, secondary metabolites of herbal extracts, and synergistic effects with other antibacterial agents have been reported (Hemeg et al., 2020). This situation led to a worldwide more investigation of herbal extracts as sources of antibacterial agents (Erfan and Marouf, 2019).

Direct use of herbal extracts is limited because of their low-solubility, instability, poor bioavailability, and high dose-related toxicity. However, it has lower toxicity and fewer side effects than synthetic drugs and chemicals (Mukherjee, 2019). Therefore, it is essential to use herbal extracts with antimicrobial effects instead of synthetic drugs and antibiotics (Matouskova et al., 2016). One of the ways how herbs are extracted is Maceration. The first process is to cut the dry herb material into small pieces in the maceration method and incubate the dry herb material in a container with the solvent. After the incubation, it is filtrated, and the extraction is complete. The maceration method's efficiency can be increased by shaking the container containing the solvent (Azmir et al., 2013).

Currently, antibiotic resistance has become a growing global public health problem. The development of antibiotic-resistant pathogen strains is a serious threat to treatment of microbial diseases (Gishen et al., 2020; Hemeg et al., 2020). Antimicrobials are substances that can inhibit or inactivate microorganisms (Mariottini and Grice, 2016). Antimicrobials are used in the food industry for two main reasons. One is to control the natural degradation processes, and the other is to prevent the growth of microorganisms, including pathogens (Stefanakis et al., 2013). The resistance of L. monocytogenes strains isolated from food to antibiotics used in the treatment of human listeriosis such as penicillin, ampicillin, tetracycline, and gentamicin, has been reported (Olaimat et al., 2018). The control of L. monocytogenes, an important agent of foodborne diseases, with various herbal extracts is being investigated (Ryser et al., 2019). L. monocytogenes can be found in several foods, especially meat and meat products, milk and dairy products, seafood, eggs, vegetables, and ready-to-eat foods (Fancello et al., 2020). L. monocytogenes has very high morbidity and mortality rates with more fatality in the elderly, newborns, pregnant women, and immunocompromised individuals. In addition, listeriosis caused by L. monocytogenes, can cause serious diseases such as meningitis, septicemia, endocarditis and meningoencephalitis (Cho et al., 2020).
This study was aimed to evaluate antibacterial effect of the herbs extracted in four different solvents: ethanol, chloroform, acetone, and distilled water against $L$. monocytogenes. For this purpose, 16 different plants were used, and their antibacterial effect against L. monocytogenes strains was determined by the disk diffusion method.

\section{Materials and Methods}

\section{Materials}

Herbs

In the study, 16 different herbs purchased from herbalists in Ankara and Afyonkarahisar were used. The herbs used in the study were St. John's Wort (Hypericum perforatum $\mathrm{L}$ ), rosemary (Rosmarinus officinalis $\mathrm{L}$ ), thyme (Thymus capitatus), marjoram (Origanum majorana), echinacea (Echinacea purpurea), olive leaf (Folium olivarum), Myrtus (Myrtus communis L) leaf, laurel (Laurus nobilis L) leaf, yarrow (Achillea millefolium L), blackberry (Rubus ulmifolius) leaf, eucalyptus (Eucalyptus globulus) leaf, calendula (Calendula officinalis L) flower, peppermint (Mentha x piperita), Sideritis akmanii (Afyonkarahisar endemic plant), mountain thyme (Thymus vulgaris), and chamomilla (Matricaria chamomilla) flower.

\section{Bacterial Strains}

In the study, 29 different Listeria monocytogenes strains previously isolated from ready-to-eat foods and one reference strain (L. monocytogenes ATCC 7644) were used. All strains were obtained from Ankara University, Department of Food Engineering, Food Microbiology Laboratories culture collection and stored at $-20^{\circ} \mathrm{C}$ in $30 \%$ (v/v) glycerol (Merck ${ }^{\mathrm{TM}}$, Germany) until analysis began. The culturing of L. monocytogenes strains was carried out in Tryptic Soy Broth (TSB) (Sigma ${ }^{\mathrm{TM}}$, Germany) at $35^{\circ} \mathrm{C}$ for $24 \mathrm{~h}$ (Şanlıbaba et al., 2018).

\section{Methods}

Preparation of Herbal Extracts

All herbs were supplied dried. The herbs were cut into pieces, pulverized, or lightly crushed according to herb parts and stored in a dry and room temperature environment until the maceration process. Firstly, each herb sample $(20 \mathrm{~g})$ was weighed for Maceration. The mechanically shredded herbs were extracted with each of the solvents. In the study, $100 \mathrm{~mL}$ of each solvent, i.e., ethanol (Merck ${ }^{\mathrm{TM}}$, Germany) (purity $\geq 99.9 \%$ ), acetone (Sigma $^{\mathrm{TM}}$, Germany) (purity $\geq 99.5 \%$ ), chloroform (Merck $^{\mathrm{TM}}$, Germany) (purity $\geq 99.0-99.4 \%$ ), and distilled water, were used. This mixture was extracted for $48 \mathrm{~h}$ in a shaking incubator at $30^{\circ} \mathrm{C}$ and $150 \mathrm{rpm}$. The extracted herbs were filtered through Whatman 1 pore size filter papers and sterilized by passing through $0.45 \mu \mathrm{m}$ pore size membrane filters (Denev et al., 2014).

\section{Determination of Antibacterial Activity}

This study was carried out to evaluate antibacterial effect of herbal extracts against L. monocytogenes strains using the agar disk diffusion method (de Aguiar et al., 2018). Sterile herbal extracts (approximately $20 \mu \mathrm{L}$ ) were impregnated into $6 \mathrm{~mm}$ diameter sterile discs (Oxoid Ltd, ES). The discs soaked with the plant extracts were kept at 
room temperature for 3-4 h. The bacterial suspension was adjusted to the $0.5 \mathrm{McFarland}$ turbidity standard $\left(1.5 \times 10^{8}\right.$ $\mathrm{CFU} / \mathrm{mL})$ using sterile TSB. The bacterial suspension (10 $\mathrm{mL}$ ) was added to $90 \mathrm{~mL}$ Tryptic Soy Agar (TSA) (Sigma $^{\mathrm{TM}}$, Germany), mixed on a shaker, and poured into sterile Petri dishes. The discs soaked with herb extract were placed on Petri dishes. The discs soaked in sterile distilled water were used as negative controls and those in gentamicin $(10 \mu \mathrm{g} / \mathrm{disc})$, as positive control. Finally, Petri dishes with the discs were kept at room temperature for 45 min and incubated at $37^{\circ} \mathrm{C}$ for $24 \mathrm{~h}$. After the incubation process, the resulting inhibition zone diameters were measured using a ruler. The antibacterial effect of different herbal extracts on L. monocytogenes strains were classified as follows: not effective for diameter less than $6 \mathrm{~mm}$; lesseffective for 6-10 mm diameter; moderately- effective for 10-15 $\mathrm{mm}$ and very effective for diameter greater than 15 $\mathrm{mm}$. All analyzes were done in duplicate.

\section{Statistical Analysis}

In the present study, measurements for quantitative variables were summarized as mean and standard deviation. The obtained measurements were analyzed using analysis of variance in repeated measures (ANOVA). The main and interaction effects of repeated measurements were insignificant in the first experiment. Hence, the model was constructed and tested as an interactive model with two factors (herbal extract and solvent type). Since the interaction effect was found to be significant, measurement means for solvents in each herbal extract were tested using the Bonferroni correction. The significance level was accepted at $5 \%$, and analyses were performed using SPSS (Version 25) software.

\section{Results and Discussion}

In this study, the antibacterial effects of extracts obtained from 16 different herbs against L. monocytogenes strains were investigated. The inhibition zones were measured based on the transparent zones formed around the discs, and the average values of the zones formed around the discs are given in Table 1. According to the variance analysis results, the interaction effect between the two factors was significant $(\mathrm{F}=47.306 ; \mathrm{P}<0.001)$. The zone diameters of the different herbal extracts obtained from different solvents against $L$. monocytogenes strains were differed.

It was found that the extract showing the highest antibacterial activity was St. John's Wort extracted in ethanol $(31.72 \pm 0.52 \mathrm{~mm})$, followed by Myrtus leaf in ethanol $(27.2 \pm 0.52 \mathrm{~mm})$, St. John's Wort in acetone (25.6 $\pm 0.52 \mathrm{~mm})$, Myrtus leaf in acetone $(22.48 \pm 0.52 \mathrm{~mm})$ and chloroform extracted Myrtus leaf $(21.75 \pm 0.52 \mathrm{~mm})$. Conversely, extracts of marjoram and yarrow did not show antibacterial effects in any solvent used in the study. The formation of the inhibition zone around the disc with herbal extract is shown in Figure 1.

In this study, the average zone diameters of St. John's Wort extract in the four different solvents were as follows: $31.72 \pm 0.52 \mathrm{~mm}$ for ethanol; $25.6 \pm 0.52 \mathrm{~mm}$ for acetone; $14.47 \pm 0.52 \mathrm{~mm}$ for chloroform; $6.2 \pm 0.52 \mathrm{~mm}$ for distilled water.

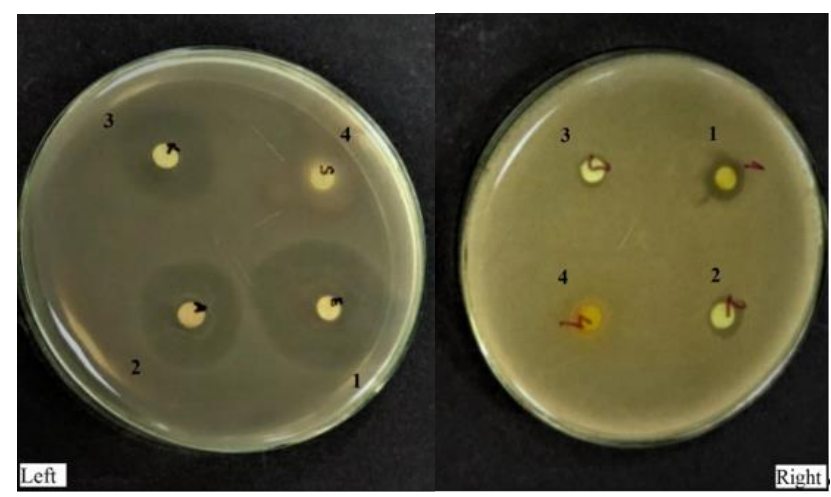

Figure 1. Inhibition zones around the disc formed by herbal extracts in different solvents against the Listeria monocytogenes strain

(In the left picture for Myrtus leaf: disc 1: ethanol extract, disc 2: acetone extract, disc 3: chloroform extract, disc 4: distilled water; In the right picture for thyme: disc 1: ethanol extract, disc 2: acetone extract, disc 3: chloroform extract, disc 4: distilled water)

Accordingly, St. John's Wort extracted in ethanol or acetone was found to be very effective, while the chloroform extract was moderately effective and distilled water extract was less-effective. Studies on St. John's Wort showed the contribution of two bioactive compounds to their antibacterial effect, namely, hyperforin and hypericin. Hyperforin is a lipophilic compound with antibacterial activity, while hypericin belongs to the flavonoids group with antibacterial and antiviral properties (Rahnavard, 2015; Sönmez and Seval, 2019). St. John's Wort was reported to have antibacterial activity against several bacteria such as Escherichia coli, Staphylococcus aureus, Pseudomonas aeruginosa, and Bacillus subtilis (Bilenler and Gökbulut, 2019; Ballı and Ulusoy Yamak, 2020). Cecchini et al. (2007) investigated St. John's Wort's methanol-acetone extracts' antibacterial effect, with the largest inhibition zone diameters found to be $15 \mathrm{~mm}$ for $S$. aureus, $14 \mathrm{~mm}$ for E. coli, and $10 \mathrm{~mm}$ for E. faecalis. A similar study determined that St. John's Wort extracted in methanol exhibited antibacterial activity against $B$. subtilis with an inhibition zone of $19.33 \mathrm{~mm}$ (Nawchoo et al., 2012). Çelen et al. (2008) found that St. John's Wort extracted in the mixture of acetone: water $(70: 30 \mathrm{v} / \mathrm{v})$ was very effective to $S$. aureus $(27 \mathrm{~mm})$ and B. subtilis $(22$ $\mathrm{mm})$. In addition, it was found that the extract of St. John's Wort in water was moderately effective to E. coli $(14 \mathrm{~mm})$ and very effective to $B$. subtilis $(17 \mathrm{~mm})$ (Çelen et al., 2008). When the data obtained in the present study and other studies were compared, St. John's Wort's antibacterial effect extracted in distilled water on $L$. monocytogenes was found to be lower. However, the antibacterial effective of acetone extract of St. John's Wort used in this study was concordant with other studies with acetone.

Myrtus leaf was another herb that showed an antibacterial effect against $L$. monocytogenes. The mean zone of the extracts of Myrtus leaf obtained with ethanol, acetone, chloroform, and distilled water against $L$. monocytogenes varied between $6.35 \pm 0.52$ and $27.2 \pm 0.52$ $\mathrm{mm}$. It was found that Myrtus leaf extracted in ethanol, acetone, and chloroform was very effective to $L$. monocytogenes, whereas the distilled water extract was less effective. 
Table 1. Average zone diameters $(\mathrm{mm})$ and standard deviation values of herbal extracts according to different solvents*

\begin{tabular}{l|cccc}
\hline \multicolumn{1}{c|}{ Herbs } & Acetone & Ethanol & Chloroform & Distilled water \\
\hline Marjoram & $6 \pm 0.52^{\mathrm{a}}$ & $6 \pm 0.52^{\mathrm{a}}$ & $6 \pm 0.52^{\mathrm{a}}$ & $6 \pm 0.52^{\mathrm{a}}$ \\
Yarrow & $6 \pm 0.52^{\mathrm{a}}$ & $6 \pm 0.52^{\mathrm{a}}$ & $6 \pm 0.52^{\mathrm{a}}$ & $6 \pm 0.52^{\mathrm{a}}$ \\
Calendula flower & $6.03 \pm 0.52^{\mathrm{a}}$ & $6.32 \pm 0.52^{\mathrm{a}}$ & $6.03 \pm 0.52^{\mathrm{a}}$ & $6.6 \pm 0.52^{\mathrm{a}}$ \\
Chamomilla flower & $6.05 \pm 0.52^{\mathrm{a}}$ & $6 \pm 0.52^{\mathrm{a}}$ & $6 \pm 0.52^{\mathrm{a}}$ & $6 \pm 0.52^{\mathrm{a}}$ \\
Blackberry leaf & $6.07 \pm 0.52^{\mathrm{a}}$ & $6.18 \pm 0.52^{\mathrm{a}}$ & $6 \pm 0.52^{\mathrm{a}}$ & $6.1 \pm 0.52^{\mathrm{a}}$ \\
Eucalyptus leaf & $6.07 \pm 0.52^{\mathrm{a}}$ & $6.35 \pm 0.52^{\mathrm{a}}$ & $6.12 \pm 0.52^{\mathrm{a}}$ & $6.27 \pm 0.52^{\mathrm{a}}$ \\
Peppermint & $6.12 \pm 0.52^{\mathrm{a}}$ & $6.32 \pm 0.52^{\mathrm{a}}$ & $6.07 \pm 0.52^{\mathrm{a}}$ & $7.03 \pm 0.52^{\mathrm{a}}$ \\
Olive leaf & $6.13 \pm 0.52^{\mathrm{a}}$ & $6.02 \pm 0.52^{\mathrm{a}}$ & $6 \pm 0.52^{\mathrm{a}}$ & $6 \pm 0.52^{\mathrm{a}}$ \\
Sideritis akmanii & $6.43 \pm 0.52^{\mathrm{a}}$ & $6.42 \pm 0.52^{\mathrm{a}}$ & $6 \pm 0.52^{\mathrm{a}}$ & $6.53 \pm 0.52^{\mathrm{a}}$ \\
Echinacea & $6.53 \pm 0.52^{\mathrm{a}}$ & $6.35 \pm 0.52^{\mathrm{a}}$ & $6.42 \pm 0.52^{\mathrm{a}}$ & $6 \pm 0.52^{\mathrm{a}}$ \\
Thyme & $6.53 \pm 0.52^{\mathrm{a}}$ & $7.1 \pm 0.52^{\mathrm{a}}$ & $6.45 \pm 0.52^{\mathrm{a}}$ & $6.13 \pm 0.52^{\mathrm{a}}$ \\
Mountain thyme & $6.72 \pm 0.52^{\mathrm{a}}$ & $6.3 \pm 0.52^{\mathrm{a}}$ & $6.42 \pm 0.52^{\mathrm{a}}$ & $6.12 \pm 0.52^{\mathrm{a}}$ \\
Laurel leaf & $6.9 \pm 0.52^{\mathrm{a}}$ & $6.7 \pm 0.52^{\mathrm{a}}$ & $6.33 \pm 0.52^{\mathrm{a}}$ & $6.12 \pm 0.52^{\mathrm{a}}$ \\
Rosemary & $11.17 \pm 0.52^{\mathrm{a}}$ & $6.67 \pm 0.52^{\mathrm{b}}$ & $6.97 \pm 0.52^{\mathrm{b}}$ & $6 \pm 0.52^{\mathrm{b}}$ \\
Myrtus leaf & $22.48 \pm 0.52^{\mathrm{a}}$ & $27.2 \pm 0.52^{\mathrm{b}}$ & $21.75 \pm 0.52^{\mathrm{a}}$ & $6.35 \pm 0.52^{\mathrm{c}}$ \\
St. John's Wort & $25.6 \pm 0.52^{\mathrm{a}}$ & $31.72 \pm 0.52^{\mathrm{b}}$ & $14.47 \pm 0.52^{\mathrm{c}}$ & $6.2 \pm 0.52^{\mathrm{d}}$ \\
\hline F & &
\end{tabular}

$\mathrm{F}=47.306 ; \mathrm{P}<0.001$, * The difference between the mean values of herbal extracts in different solvents was statistically significant $(\mathrm{F}=47.306 ; \mathrm{P}<0.001)$. The model was constructed and tested as an interactive model with two factors (herbal extract and solvent type). The smallest significant difference test (LSD: Least Significant Difference) was performed for multiple comparisons to determine the source of the differences. In case of no significant difference between the groups, the mean values were indexed with the same letter.

In a study using Myrtus leaf extracted in n-hexane, methylene chloride, and methanol by Keven-Karademir and Avunduk (2015), inhibition zone diameters varied between 7-16 $\mathrm{mm}$. In that study, the highest inhibition zone values against $S$. aureus $(16 \mathrm{~mm})$, Klebsiella pneumoniae $(15 \mathrm{~mm})$, and $P$. aeruginosa $(12 \mathrm{~mm})$ were observed at concentrations of $10 \%$ (Keven-Karademir and Avunduk, 2015). In our study, ethanol extracts of Myrtus leaf were very effective to $L$. monocytogenes with an average inhibition zone diameter of $27.2 \pm 0.52 \mathrm{~mm}$. However, Mert et al. (2008) reported that the Myrtus leaf extracted in the water had an inhibition zone diameter of $15 \mathrm{~mm}$ at most and moderately effective against $S$. aureus ATCC 6538P and S. aureus ATCC 29213. On the other hand, our study determined that Myrtus leaf extracted in distilled water was less effective to L. monocytogenes with an average inhibition zone diameter of $6.35 \pm 0.52 \mathrm{~mm}$.

Present study found that acetone extract of rosemary had higher antibacterial activity against $L$. monocytogenes than other solvent extracts of rosemary. Rosemary extracted in acetone showed moderate effective to $L$. monocytogenes with an average inhibition zone of $11.17 \pm 0.52 \mathrm{~mm}$. However, rosemary extracted in other solvents was not effective to L. monocytogenes. Celiktas et al. (2007) reported in their study that methanol extracts of rosemary showed low activity against $S$. aureus but ineffective against other microorganisms. However, in another study, rosemary extracted in ethanol and dichloromethane had a high antimicrobial effect against $E$. coli and Pseudomonas sp., with inhibition zone diameters ranging from $16.6-26 \mathrm{~mm}$ (Lahlou et al., 2019). The antibacterial effect of rosemary is suggested to be due to its compounds such as flavonoids and phenolics (Lahlou et al., 2019).

All extracts of thyme and peppermint were less effective to L. monocytogenes. It was determined that the ethanol extract of thyme showed the highest antibacterial effect $(7.1 \pm 0.52 \mathrm{~mm})$ among thyme extracts. Also, the distilled water extract of peppermint showed the highest antibacterial effect $(7.03 \pm 0.52 \mathrm{~mm})$ among peppermint extracts. However, all extracts of chamomile flower, except acetone extract, were ineffective against $L$. monocytogenes. On the other hand, Bayoub et al. (2010) found that $L$. monocytogenes was very- effective to peppermint ethanol extracts and moderately effective to extracts of chamomile, thyme, and rosemary. This difference between studies may be due to differences in the extraction method and the herbs' bioactive compound content.

All extracts of marjoram and yarrow were not effective to L. monocytogenes. However, these results differ from the results of the other studies. Dinçoğlu (2019) found that the extract of marjoram in ethanol was very effective to $S$. aureus, while its chloroform extract showed lesssensitivity to Campylobacter jejuni. However, marjoram extracts did not show an antibacterial effect against Brucella spp. (Dinçoğlu, 2019). In another study, it was determined that the yarrow ethanol extract showed a moderately effective against Yersinia enterocolitica and Streptococcus salivarius (mean zone 10-11 mm) and very effective to $S$. aureus (21 mm) (Grigore et al., 2020).

Phenolic compounds derived from olive leaves are potential antioxidants and antimicrobial agents (Altemimi, 2017). In our study, only acetone and ethanol extracts of olive leaf showed a less effective antibacterial effect, and its extracts in other solvents were ineffective. On the other hand, 5\% hot water extract of naturally dried olive leaf (Ayvalık) was found to have antimicrobial effects against E. coli, L. monocytogenes, and S. aureus (Kobya et al., 2019). Additionally, extracts of olive leaf in water were not effective to any test bacteria used in the study (Korukluoglu et al., 2008). However, an antibacterial effect of olive leaf extracted in acetone was found against $B$. cereus, E. coli, Salmonella enteritidis, Enterococcus faecalis, Streptococcus thermophiles, Lactobacillus bulgaricus, and Klebsiella pneumoniae (Korukluoglu et al., 2008).

In this study, all solvent extracts of calendula flower, mountain thyme, laurel leaf, and eucalyptus leaf were found to be less effective to L. monocytogenes. The extract 
with the most antibacterial effect was laurel leaf extract in acetone with an average inhibition zone diameter of $6.9 \pm 0.52 \mathrm{~mm}$. Laurel leaf contains compounds with potent inhibitory activity such as eugenol, cineole, $\gamma$-pinene, and methyl eugenol (El Malti and Amarouch, 2009). El Malti and Amarouch (2009) reported that laurel extracts have antibacterial effects ranging from $7.2 \mathrm{~mm}$ (Pseudomonas aeruginosa ATCC 27853) to $20.2 \mathrm{~mm}$ (L. monocytogenes). However, in a study with calendula flower extract, no antimicrobial effect was observed against $P$. aeruginosa and Candida albicans (Herman et al., 2013). Conversely, inhibition zone diameters of $8 \mathrm{~mm}$ were obtained against $S$. aureus and $7 \mathrm{~mm}$ against E. coli (Herman et al., 2013). The antibacterial susceptibility results of calendula flower extracts in this study and other studies were concordant. Zwetlana et al. (2014) found that the eucalyptus leaf extract in water was effective against Pseudomonas sp. (17 mm), and its ethanol extract was effective against Klebsiella sp. and $E$. coli (20 $\mathrm{mm}$ and $22 \mathrm{~mm}$, respectively).

According to this study results, all extracts of echinacea except water showed less effective antibacterial activity. However, the solvent with the highest antibacterial activity against L. monocytogenes was acetone $(6.53 \pm 0.52 \mathrm{~mm})$. Similarly, Coelho et al. (2020) examined the antimicrobial effect of echinacea in seven different solvents and determined that acetone extracts had the highest antibacterial effect. In contrast, echinacea extracts in water in our study did not show antibacterial effects against $L$. monocytogenes.

The extracts of blackberry leaf and Sideritis akmanii in ethanol, distilled water, and acetone showed less effective activity against $L$. monocytogenes. No antibacterial effect was found with blackberry leaf and Sideritis akmanii chloroform extracts. Denev et al. (2014) reported that the acetone extract of blackberry leaf had an antimicrobial effect against all test bacteria and the largest inhibition zone diameter against L. monocytogenes $(24 \mathrm{~mm})$. Our study determined that the extracts of Sideritis akmanii, an endemic plant growing in Afyonkarahisar, in distilled water are less effective to L. monocytogenes $(6.53 \pm 0.52$ $\mathrm{mm})$. Also, Temel et al. (2014) reported in their study that Sideritis akmanii extracts had an antibacterial effect $(13.00 \pm 3.16 \mathrm{~mm})$ against $L$. monocytogenes at a concentration of $20 \%$.

\section{Conclusions}

In our study, the antibacterial effect of herbs extracted in ethanol, acetone, chloroform, and distilled water against L. monocytogenes strains was determined using the disc diffusion method. St. John's Wort and Myrtus leaf extracted in ethanol and acetone was found to be promising. However, no effective results were obtained from the extracts of the herbs in distilled water. Herbal extracts can be used to inactivate or reduce for the pathogen growth in foods. Finally, more studies are needed to use herbal extracts safely in foods and prove their antibacterial effects for more pathogens.

\section{Conflict of Interest}

The authors express no conflict of interest associated with this work.

\section{References}

Altemimi AB. 2017. A study of the protective properties of Iraqi olive leaves against oxidation and pathogenic bacteria in food applications. Antioxidants, 6(2): 34. https://doi.org/10.3390/ antiox6020034

Azmir J, Zaidul ISM, Rahman MM, Sharif KM, Mohamed A, et al. 2013. Techniques for extraction of bioactive compounds from plant materials: A review. Journal of food engineering, 117(4): 426-436. https://doi.org/10.1016/j.jfoodeng.2013.01. 014

Ballı F, Ulusoy Yamak AT. 2020. Assessment of the Antimicrobial Effectiveness of Hypericum perforatum L. and Secondary Metabolites against Pathogenic Oral Bacteria. Black Sea Journal of Health Science, 1-2.

Bayoub K, Baibai T, Mountassif D, Retmane A, Soukri A. 2010. Antibacterial activities of the crude ethanol extracts of medicinal plants against Listeria monocytogenes and some other pathogenic strains. African Journal of Biotechnology, 9(27): 4251-4258.

Bilenler T, Gökbulut İ. 2019. Hastane Patojenlerinin Ticari Uçucu Yağlara Karşı Hassasiyetlerinin Belirlenmesi. Gümüşhane Üniversitesi Fen Bilimleri Enstitüsü Dergisi, 9(4): 716-723. https://doi.org/10.17714/gumusfenbil. 537244

Cecchini C, Cresci A, Coman MM, Ricciutelli M, Sagratini G, et al. 2007. Antimicrobial activity of seven Hypericum entities from central Italy. Planta medica, 73(06): 564-566. https://doi.org/10.1055/s-2007-967198

Celiktas OY, Kocabas EH, Bedir E, Sukan FV, Ozek T, Baser KHC. 2007. Antimicrobial activities of methanol extracts and essential oils of Rosmarinus officinalis, depending on location and seasonal variations. Food Chemistry, 100(2): 553-559. https://doi.org/10.1016/j.foodchem.2005.10.011

Cho Y, Kim H, Beuchat LR, Ryu JH. 2020. Synergistic activities of gaseous oregano and thyme thymol essential oils against Listeria monocytogenes on surfaces of a laboratory medium and radish sprouts. Food Microbiology, 86: 103357. https://doi.org/10.1016/j.fm.2019.103357

Coelho J, Barros L, Dias MI, Finimundy TC, Amaral JS, et al. 2020. Echinacea purpurea (L.) Moench: Chemical Characterization and Bioactivity of its Extracts and Fractions. Pharmaceuticals, 13(6): 125. https://doi.org/10.3390/ph1306 0125

Çelen G, Ozkan S, Ayhan F. 2008. The phenolic compounds from Hypericum perforatum and their antimicrobial activities. Hacettepe Journal of Biology and Chemistry, 36(4): 339-345. de Aguiar FC, Solarte AL, Tarradas C, Luque I, Maldonado A, Galán-Relaño Á, Huerta B. 2018. Antimicrobial activity of selected essential oils against Streptococcus suis isolated from pigs. Microbiology open, 7(6): e00613. https:// doi.org/10.1002/mbo3.613

Denev P, Kratchanova M, Ciz M, Lojek A, Vasicek O, et al. 2014. Antioxidant, antimicrobial and neutrophil-modulating activities of herb extracts. Acta Biochimica Polonica, 61(2): https://doi.org/10.18388/abp.2014_1907

Dinçoğlu AH. 2019. Mercanköşk (Origanum Onites L.) Bitkisinin Bazı Gıda Patojenleri Üzerine Antibakteriyel Etkinliğinin Saptanması. MAKU J Health Sci Inst, 7(2): 139146. https://doi.org/10.24998/maeusabed.656858

Elisha IL, Botha FS, McGaw LJ, Eloff JN. 2017. The antibacterial activity of extracts of nine plant species with good activity against Escherichia coli against five other bacteria and cytotoxicity of extracts. BMC complementary and alternative medicine, 17(1): 1-10. https://doi.org/10.1186/s12906-017$1645-\mathrm{z}$

El Malti J, Amarouch H. 2009. Antibacterial effect, histological impact and oxidative stress studies from Laurus nobilis extract. Journal Food Quality, 32(2): 190-208. https://doi.org/10.1111/j.1745-4557.2009.00245.x 
Erfan AM, Marouf S. 2019. Cinnamon oil downregulates virulence genes of poultry respiratory bacterial agents and revealed significant bacterial inhibition: $A n$ in vitro perspective. Veterinary World, 12(11): 1707. https://dx.doi. org/10.14202\%2Fvetworld.2019.1707-1715

Fancello F, Petretto GL, Marceddu S, Venditti T, Pintore G, et al. 2020. Antimicrobial activity of gaseous Citrus limon var pompia leaf essential oil against Listeria monocytogenes on ricotta salata cheese. Food Microbiology, 87: 103386. https://doi.org/10.1016/j.fm.2019.103386

Gishen NZ, Taddese S, Zenebe T, Dires K, Tedla A, et al. 2020. In vitro antimicrobial activity of six Ethiopian medicinal plants against Staphylococcus aureus, Escherichia coli and Candida albicans. European Journal of Integrative Medicine, 36: 101121. https://doi.org/10.1016/j.eujim.2020.101121

Grigore A, Colceru-Mihul S, Bazdoaca C, Yuksel R, Ionita C, Glava L. 2020. Antimicrobial Activity of an Achillea millefolium L. Multidisciplinary Digital Publishing Institute Proceedings, 57(1): 34. https://doi.org/10.3390/proceedings2 020057034

Gyawali R, Ibrahim SA. 2014. Natural products as antimicrobial agents. Food Control, 46: 412-429. https://doi.org/10.1016/ j.foodcont.2014.05.047

Hemeg HA, Moussa IM, Ibrahim S, Dawoud TM, Alhaji JH, et al. 2020. Antimicrobial effect of different herbal plant extracts against different microbial population. Saudi Journal of Biological Sciences, 27(12): 3221-3227. https://doi.org/ 10.1016/j.sjbs.2020.08.015

Herman A, Herman AP, Domagalska BW, Młynarczyk A. 2013. Essential oils and herbal extracts as antimicrobial agents in cosmetic emulsion. Indian Journal of Microbiology, 53(2): 232-237. https://doi.org/10.1007/s12088-012-0329-0

Karim N, Jia Z, Zheng X, Cui S, Chen W. 2018. A recent review of citrus flavanone naringenin on metabolic diseases and its potential sources for high yield-production. Trends Food Science Technology, 79: 35-54. https://doi.org/10.1016/ j.tifs.2018.06.012

Keven-Karademir F, Avunduk S. 2015. Antibacterial and antioxidant activity of Myrtus communis L. growing wild in Marmaris. G1da/The Journal of Food, 40(4): p193-199.

Kobya O, Çağlak E, Kara B. 2019. Comparison of Antioxidant and Antimicrobial Effects of Extracts obtained by Drying Olive Leaves (Olea europaea L.) Collected from BalıkesirAyvalık and Trabzon-Çarşıbaşı. Journal of anatolian environmental and animal sciences, 4(2): 257-262. https://doi.org/10.35229/jaes.584408

Korukluoglu M, Sahan Y, Yigit A. 2008. Antifungal properties of olive leaf extracts and their phenolic compounds. Journal of Food Safety, 28(1): 76-87. https://doi.org/10.1111/j.17454565.2007.00096.x

Lahlou Y, El Amraoui B, Bamhaoud T. 2019. The Antibacterial Activity Screening of the Extracts of Some Moroccan Medicinal Plants. International Journal of New Technology and Research (IJNTR), 5, 31-38.

Mariottini GL, Grice ID. 2016. Antimicrobials from Cnidarians. A new perspective for anti-infective therapy? Marine Drugs, 14(3): 48. https://doi.org/10.3390/md14030048

Matouskova P, Marova I, Bokrova J, Benesova P. 2016. Effect of encapsulation on antimicrobial activity of herbal extracts with lysozyme. Food technology and biotechnology, 54(3): 304316. https://doi.org/10.17113/ftb.54.03.16.4413

Mert T, Fafal T, Kıvçak B. 2008. Antimicrobial and Cytotoxic Activities of Myrtus communis L. Ankara Üniversitesi Eczacılık Fakültesi Dergisi, 37(3): 191-199. https://doi.org/ 10.1501/Eczfak_0000000501
Mukherjee PK. 2019. Quality control and evaluation of herbal drugs: Evaluating natural products and traditional medicine. Elsevier, 573-598. https://doi.org/10.1016/B978-0-12813374-3.00015-6

Nawchoo IA, Yousuf M, Aslam K, Wani BA, Dar NA. 2012. In vitro antibacterial activity and phytochemical studies of methanolic extract of leaves of Hypericum perforatum L. growing wild in Kashmir Himalaya. Asian Journal of Plant Science and Research, 2(4): 414-420

Olaimat AN, Al-Holy MA, Shahbaz HM, AlNabulsi AA, AbuGhoush MH, Osaili TM, Ayyash MM, Holley RA. 2018. Emergence of Antibiotic Resistance in Listeria monocytogenes Isolated from Food Products: A Comprehensive Review. Comprehensive Reviews in Food Science and Food Safety, 17(5): 1277-1292. https:// doi.org/10.1111/1541-4337.12387

Rahnavard A. 2015. Cultivated Hypericum perforatum Hypericin Extracts' Antibacterial Effect against Susceptile and Methicillin-Resistant Staphylococcus aureus. International Journal of Molecular and Clinical Microbiology, 5(2): 549555.

Ryser ET, Buchanan RL, den Bakker HC. 2019. Listeria monocytogenes. In: Doyle, M.P., Diez-Gonzalez, F., Hill, H. (Eds.), Food Microbiology: Fundamentals and Frontiers. ASM Press, Washington, DC, pp. 451-486. https:// doi.org/10.1128/9781555819972

Rodino S, Butu A, Petrache P, Butu M, Dinu-Pirvu CE, Cornea CP. 2015. Evaluation of the antimicrobial and antioxidant activity of Sambucus ebulus extract. Farmacia, 63(5): 751754.

Rodino S, Butu M. 2019. Herbal Extracts-New Trends in Functional and Medicinal Beverages. In Functional and medicinal beverages. Academic Press, pp: 73-108. https://doi.org/10.1016/B978-0-12-816397-9.00003-0

Sogut O, Sezer UA, Sezer S. 2020. Liposomal delivery systems for herbal extracts. Journal of Drug Delivery Science and Technology, 102147. https://doi.org/10.1016/j.jddst. 2020. 102147

Sönmez M, Seval M. 2019. Fitoterapik Yara Bakımında Sarı Kantaron Yağının Etkisi. Academic Studies on Natural and Health Sciences, 201.

Stefanakis MK, Touloupakis E, Anastasopoulos E, Ghanotakis D, Katerinopoulos HE, Makridis P. 2013. Antibacterial activity of essential oils from plants of the genus Origanum. Food Control, 34(2): 539-546. https://doi.org/10.1016/j.foodcont. 2013.05.024

Şanlıbaba P, Tezel BU, Çakmak GA. 2018. Prevalence and Antibiotic Resistance of Listeria monocytogenes Isolated from Ready-to-Eat Foods in Turkey. Hindawi Journal of Food Quality, Article ID 7693782, 9 pages, https://doi.org/ $10.1155 / 2018 / 7693782$

Temel M, Kara R, Muduroglu R, Akkaya L. 2014. Antibacterial activity of Turkish endemic Sideritis akmanii (Lamiaceae). Global journal for research analysis, 3: 83-4.

Zwetlana A, Nandini M, Dorcas K. 2014. Antimicrobial activity of medicinal plant extracts on gram negative bacteria. The Journal of Medicinal Plants Studies, 2(5): 51-54. 